\title{
Carcass composition of Polish Lowland and Polish Merino lambs fed diets containing different protein levels
}

\author{
J.J. Pająk, T. Żebrowska, A. Janocha' ${ }^{1}$, B. Kowalik and P. Dakowski
}

The Kielanowski Institute of Animal Physiology and Nutrition.

Polish Academy of Sciences

05-110 Jablonna, Poland

'Podlaska Academy

Prusa 14, 08-110 Siedlce, Poland

\begin{abstract}
The effect of the protein content in the diet on the tissue composition of 90 male Polish Lowland lambs fed diets containing from 13 to $18 \%$ crude protein in DM during the fattening period and on 44 carcasses of male Polish Merino lambs fed diets containing from 11 to $19 \%$ protein in DM was studied. The energy value of the diets was similar. The lambs were fattened from weaning at the age of 70-90 days to reaching a slaughter weight of $35-40 \mathrm{~kg}$ (Polish Merino) or 35-45 kg (Polish Lowland).

The Lowland lambs that received less protein in diets had somewhat lower lean content and higher fat content in the carcass than the lambs that were fed diets with a higher protein level. No significant differences were found in the carcass composition of Merino lambs. The tissue composition of the carcasses depended more on the slaughter weight of the lambs and the related carcass weight than on the protein level in the diet.
\end{abstract}

KEY WORDS: Polish Lowland lamb, Polish Merino lamb, fattening, protein, carcass

\section{INTRODUCTION}

The effect of the dietary protein level on slaughter indices and carcass composition of lambs can depend on the genetic potential and the composition of the diet.

Carcass leanness can be increased by limiting feed consumption or reducing the consumption of protein or energy in the diet (Glimp and Snowder, 1989). Coetho et al. (1986) also report that the amount of separable, kidney, and pelvic fat was significantly lower in the carcasses of lambs fed a diet containing $120 \mathrm{~g}$ of 
crude protein (CP) than in those that received $150 \mathrm{~g}$ of $\mathrm{CP}$ in DM of isoenergetic diets. In some studies (e.g., Shindarska, 1987; Sinclair et al., 1991) when the protein content of the diet was increased from about $120-130$ to $180-190 \mathrm{~g} / \mathrm{kg} \mathrm{DM}$, the opposite relationship was found. Protein deposition in the body increased, especially in the initial (to $25 \mathrm{~kg}$ body weight) period of fattening, while in the final period (to $40 \mathrm{~kg}$ body weight), more fat was deposited. According to other authors (e.g., Searle and Griffiths, 1976; Beauchemin et al., 1995) the protein or energy level in the diet has only a small influence on the body composition of fattened lambs. The composition of the gain is similar with all diets that support fast growth of lambs (Searle and Griffiths, 1976).

The objective of this study was to evaluate the effect of dietary protein level on the carcass composition of Polish Lowland and Polish Merino lambs fed diets composed according to traditional standards (IZ, 1993) or diets with reduced protein levels.

\section{MATERIAL AND METHODS}

Data from earlier experiments, including 90 carcasses of Polish Lowland lambs fed diets containing from 13 to 18\% crude protein in DM (Pająk et al., 1993, 1999, 2000 ) and 44 carcasses of male Polish Merinos lambs, which received from 11 to $19 \%$ CP in DM (Jayaprakash, 1984; Żebrowska et al., 1987; Pająk et al., 1992) was used.

The rations were composed of $15-25 \%$ meadow hay and a mixture of concentrates of varying composition with an addition of a vitamin-mineral premix. The concentrates contained a varied amount of protein; the control groups received from 16 to $19 \%$, the experimental groups, from 11 to $13-15 \%$ crude protein. The details of feeding are given in the cited above publications.

The lambs were fattened from weaning at the age of 70-90 days, to reaching a slaughter weight of 35-40 kg (Polish Merino) or 35-45 kg (Polish Lowland). After slaughter and $24 \mathrm{~h}$ cooling, the carcass composition was determined according to the method described by Pająk et al. (1999).

Statistical analysis and regression equations were performed and developed using the Statgraphics ${ }^{\circledast}$ Plus, ver. 7.0 (1993) program.

\section{RESULTS AND DISCUSSION}

The average weight of the cold carcass and carcass composition (in percentages) of Polish Lowland lambs are given in Table 1, those of Polish Merino lambs, in Table 2. 
TABLE 1

Effect of protein level in the DM diet on cold carcass composition of Polish Lowland lambs

\begin{tabular}{ccccccc}
\hline $\begin{array}{c}\text { CP/DM } \\
\mathrm{g}\end{array}$ & $\mathrm{n}$ & $\begin{array}{c}\text { Carcass } \\
\mathrm{kg}\end{array}$ & $\begin{array}{c}\text { Lean } \\
\%\end{array}$ & $\begin{array}{c}\text { Separable fat } \\
\%\end{array}$ & $\begin{array}{c}\text { Bones } \\
\%\end{array}$ & $\begin{array}{c}\text { Connected tissue } \\
\%\end{array}$ \\
\hline 131 & 5 & $18.0 \pm 1.1$ & $58.0 \pm 2.5$ & $15.6 \pm 3.2$ & $20.3 \pm 0.8$ & $6.2 \pm 0.7$ \\
142 & 27 & $17.7 \pm 2.2$ & $53.4 \pm 3.4$ & $19.1 \pm 4.8$ & $19.7 \pm 1.4$ & $7.8 \pm 1.3$ \\
149 & 26 & $18.2 \pm 2.1$ & $52.9 \pm 3.5$ & $20.2 \pm 4.8$ & $19.4 \pm 1.9$ & $7.5 \pm 1.9$ \\
162 & 26 & $16.6 \pm 2.5$ & $56.0 \pm 3.5$ & $16.2 \pm 5.0$ & $20.6 \pm 1.8$ & $7.2 \pm 1.6$ \\
178 & 6 & $14.4 \pm 0.6$ & $56.1 \pm 2.8$ & $15.2 \pm 2.0$ & $20.8 \pm 1.0$ & $7.9 \pm 1.1$ \\
\hline
\end{tabular}

$\pm \mathrm{SD}$ - standard deviation

TABLE 2

Effect of protein level in the DM diet on cold carcass composition of Polish Merino lambs

\begin{tabular}{ccccccc}
\hline $\begin{array}{c}\text { CP/DM } \\
\mathrm{g}\end{array}$ & $\mathrm{n}$ & $\begin{array}{c}\text { Carcass } \\
\mathrm{kg}\end{array}$ & $\begin{array}{c}\text { Lcan } \\
\%\end{array}$ & $\begin{array}{c}\text { Separable fat } \\
\%\end{array}$ & $\begin{array}{c}\text { Bones } \\
\%\end{array}$ & $\begin{array}{c}\text { Connected tissue } \\
\%\end{array}$ \\
\hline 110 & 4 & 16.6 & 57.9 & 13.8 & 22.7 & 5.6 \\
143 & 10 & 16.5 & 58.7 & 16.0 & 20.4 & 4.8 \\
172 & 18 & 16.3 & 57.6 & 16.5 & 21.0 & 5.0 \\
188 & 12 & 16.2 & 59.1 & 15.8 & 20.2 & 5.0 \\
\hline
\end{tabular}

In the case of Polish Lowland lambs, the protein content (X), in the DM diets $(\%)$ had a small but significant $(\mathrm{P}<0.05)$ influence on the content of meat and separable fat in the carcass $(\%)$ :

$\begin{array}{lllll}\text { lean } & \mathrm{Y}_{1\{\mathrm{CP}\}}=44.0+0.69 \mathrm{X}( \pm 0.332) & \mathrm{SE}=3.62 & \mathrm{r}=0.22 & (\mathrm{P}<0.05) \\ \text { separable fat } & \mathrm{Y}_{\mathrm{sf}(\mathrm{CP})}=34.8-1.11 \mathrm{X}( \pm 0.444) & \mathrm{SE}=4.84 & \mathrm{r}=-0.26 & (\mathrm{P}<0.05)\end{array}$

In Lowland lambs receiving a lower amount of protein in the diet, there was a tendency to deposit somewhat more separable fat in the body than in lambs fed diets with higher protein contents, which supports the results of Shindarska (1987) and Sinclair et al. (1991).

No differences were found in Merino lambs in terms of carcass meat, fat, bone, or connected tissue content depending on the amount of protein in the diet, which is in agreement with the results of Searle and Griffiths (1976), Urbaniak (1986) and Beauchemin et al. (1995).

The effect of slaughter weight of Polish Lowland lambs on carcass composition is presented in Table 3. This data was used to develop regression equations for 
TABLE 3

Effect of slaughter weight on cold carcass composition of Polish Lowland lambs, $\%$

\begin{tabular}{crccccc}
\hline $\begin{array}{c}\text { BW } \\
\mathrm{g}\end{array}$ & $\mathrm{n}$ & $\begin{array}{c}\text { Carcass } \\
\mathrm{kg}\end{array}$ & $\begin{array}{c}\text { Lean } \\
\%\end{array}$ & $\begin{array}{c}\text { Separable fat } \\
\%\end{array}$ & $\begin{array}{c}\text { Bones } \\
\%\end{array}$ & $\begin{array}{c}\text { Connected tissue } \\
\%\end{array}$ \\
\hline $25-30$ & 2 & $10.0 \pm 0.1$ & $57.9 \pm 4.7$ & $10.4 \pm 3.5$ & $23.9 \pm 0.4$ & $7.8 \pm 1.5$ \\
$30-35$ & 10 & $14.5 \pm 0.8$ & $55.5 \pm 3.2$ & $14.0 \pm 4.2$ & $21.8 \pm 1.6$ & $8.6 \pm 2.0$ \\
$35-40$ & 27 & $16.1 \pm 0.8$ & $56.1 \pm 3.0$ & $16.1 \pm 3.0$ & $20.3 \pm 1.2$ & $7.5 \pm 1.6$ \\
$40-45$ & 41 & $18.4 \pm 1.5$ & $53.6 \pm 3.5$ & $19.4 \pm 4.0$ & $19.6 \pm 1.1$ & $7.5 \pm 1.4$ \\
$45-50$ & 10 & $20.3 \pm 1.3$ & $51.7 \pm 4.4$ & $24.1 \pm 6.2$ & $18.3 \pm 1.9$ & $5.9 \pm 1.0$ \\
\hline
\end{tabular}

estimating the proportion of tissue in carcass (\%) on the basis of slaughter weight, $\mathrm{X}(\mathrm{kg})$ :

lean

separable fat $\quad \mathrm{Y}_{\mathrm{sf}(\mathrm{BW})}=0.66 \mathrm{X}( \pm 0.095)-8.7 \quad \mathrm{SE}=4.02 \quad \mathrm{r}=0.59 \quad(\mathrm{P}<0.01)$ bones $\quad \mathrm{Y}_{\mathrm{b}\langle\mathrm{BW}\}}=29.4-0.23 \mathrm{X}( \pm 0.032) \quad \mathrm{SE}=1.33 \quad \mathrm{r}=-0.62 \quad(\mathrm{P}<0.01)$ connected tissue $\mathrm{Y}_{\mathrm{ct}(\mathrm{BW})}=11.4-0.10 \mathrm{X}( \pm 0.037) \quad \mathrm{SE}=1.54 \quad \mathrm{r}=-0.27 \quad(\mathrm{P}<0.01)$

A stronger correlation was found between slaughter weight, $\mathrm{X}(\mathrm{kg})$ and cold carcass weight:

cold carcass

weight

$$
\mathrm{Y}_{\mathrm{CW}(\mathrm{BW})}=0.47 \mathrm{X}( \pm 0.026)-1.59 \mathrm{SE}=1.09 \quad \mathrm{r}=0.89 \quad(\mathrm{P}<0.01)
$$

The proportion of lean (51.7 vs $55.5 \%$ ) and bones ( 18.3 vs $21.8 \%$ ) in heavier carcasses of Lowland lambs was smaller and the proportion of separable fat was nearly two times larger ( $24.1 \mathrm{vs} 14.0 \%)$ than in the carcasses of lambs slaughtered at $30-35 \mathrm{~kg}$.

The effect of the carcass weight of Lowland lambs on the share of particular tissues is presented in Table 4.

The carcass composition (\%) can be estimated with more precision on the basis of cold carcass weight, $\mathrm{X}(\mathrm{kg})$, than on slaughter weight:

lean

separable fat

$$
\begin{array}{lllll}
\text { lean } & \mathrm{Y}_{\mathrm{I}(\mathrm{CW})}=69.1-0.84 \mathrm{X}( \pm 0.140) & \mathrm{SE}=3.12 & \mathrm{r}=-0.54 & (\mathrm{P}<0.01) \\
\text { separable fat } & \mathrm{Y}_{\mathrm{sf}(\mathrm{CW})}=1.55 \mathrm{X}( \pm 0.153)-8.7 & \mathrm{SE}=3.40 & \mathrm{r}=0.73 & (\mathrm{P}<0.01) \\
\text { bones } & \mathrm{Y}_{\mathrm{b}(\mathrm{CW})}=28.9-0.52 \mathrm{X}( \pm 0.053) & \mathrm{SE}=1.17 & \mathrm{r}=-0.72 & (\mathrm{P}<0.01) \\
\text { connected tissue } & \mathrm{Y}_{\mathrm{ct}(\mathrm{CW})}=10.7-0.19 \mathrm{X}( \pm 0.069) & \mathrm{SE}=1.54 & \mathrm{r}=-0.28 & (\mathrm{P}<0.01)
\end{array}
$$

In conclusion, reducing of the protein content in diets by 4-5 percentage points per $\mathrm{kg}$ DM intake does not cause a significant deterioration of carcass quality of lambs. Separable fat (pelvic and kidney) and intramuscular and subcutaneous fat are discarded during cooking. Therefore, the tendency for a rise in the fat content 
TABLE 4

Effect of cold carcass weight on carcass composition of Polish Lowland lambs, \%

\begin{tabular}{lrccccc}
\hline $\begin{array}{l}\text { Carcass } \\
\mathrm{kg}\end{array}$ & $\mathrm{n}$ & $\begin{array}{c}\mathrm{BW} \\
\mathrm{kg}\end{array}$ & $\begin{array}{c}\text { Lean } \\
\%\end{array}$ & $\begin{array}{c}\text { Scparable fat } \\
\%\end{array}$ & $\begin{array}{c}\text { Bones } \\
\%\end{array}$ & $\begin{array}{c}\text { Connected tissue } \\
\%\end{array}$ \\
\hline $10.1-15$ & 9 & $32.4 \pm 3.9$ & $57.7 \pm 2.0$ & $11.7 \pm 3.5$ & $22.1 \pm 1.8$ & $8.4 \pm 2.0$ \\
$15.1-17.5$ & 38 & $38.3 \pm 2.4$ & $55.7 \pm 3.2$ & $16.3 \pm 2.8$ & $20.5 \pm 1.3$ & $7.6 \pm 1.4$ \\
$17.6-20$ & 30 & $43.1 \pm 1.8$ & $53.5 \pm 3.3$ & $19.7 \pm 3.6$ & $19.5 \pm 1.1$ & $7.2 \pm 1.6$ \\
$20.1-22.5$ & 13 & $45.3 \pm 2.2$ & $50.8 \pm 3.4$ & $24.3 \pm 5.4$ & $18.1 \pm 1.7$ & $6.7 \pm 1.4$ \\
\hline
\end{tabular}

of carcasses of lambs fed diets with reduced protein levels may have an unfavourable effect on the price of mutton, but is not a significant barrier to using diets with $14 \%$ protein in DM.

Regression equations used to estimate carcass composition based on cold carcass weight can be used for commercial purposes, including meat processing. The protein content of diets in fattened lambs is not sufficient to estimate lamb carcass composition.

\section{CONCLUSIONS}

Reducing the protein content in the diets of fattened Polish Lowland and Polish Merino lambs from $18-19 \%$ to about $14 \%$ in DM do not significantly affect carcass composition, although in Lowland lambs there is an unfavourable tendency for them to deposit more fat when the protein level in the diet is lowered.

Carcass composition depends more on slaughter weight and the related carcass weight than on the level of protein in the diet.

\section{REFERENCES}

Beauchemin K.A., McClelland L.A., Jones S.D.M., Kozub G.C., 1995. Effects of crude protein content, protein degradability and energy concentration of the diet on growth and carcass characteristics of market lambs fed high concentrate diets. Can. J. Anim. Sci. 75, 387-395

Coetho J.F.S., Galbraith H., Topps J.H., 1986. Response of wether lambs to implantation with trenbolone acetate combined with oestradiol-17beta at two levels of dictary protein. Ann. Zootech. $35,315-328$

Glimp H.A., Snowder G.D., 1989. Production methods to increase lean and reduce fat in lamb: a review. Sheep Res. J. 5 (3), 18-27

IZ, Nutrient Requirements of Cattle and Sheep, Traditional System (in Polish), 1993. R. Ryś (Editor). Research Institute of Animal Production, Kraków (Poland), pp. 103 
Jayaprakash., 1984. Influence of various sources of nitrogen in the diet on the digestiblity, nitrogen metabolism, growth and carcass composition of Polish Merino lambs. Ph.D. Thesis. The Kielanowski Institute of Animal Physiology and Nutrition, Jablonna (Poland)

Pająk J.J., Słowak M., Dakowski P., 1993. Fattening performance of Polish Lowland lambs related to protein level in the diet. J. Anim. Feed Sci. 1, 193-203

Pająk J.J., Żebrowska T., Słowak M., Długołęcka Z., 1999 Body composition of Polish Lowland lambs fattened on diets with restricted protein level (in Polish). Ann. Warsaw Agr. Univ. - SGGW, Anim. Sci. 36, 57-62

Pająk J.J., Żebrowska T., Słowak M., Długołęcka Z., 2000. Fattening of Polish Lowland lambs on diets with different energy and protein levels. J. Anim. Feed Sci. 9, 447-460

Pająk J., Żebrowska T., Żebrowska H., 1992. Protein content in the diet for fattening lambs. 2. The chemical and amino acid composition of the body and utilization of amino acids apparently absorbed in the small intestine. J. Anim. Feed Sci. 1, 27-36

Shindarska Z., 1987. Effect of the energy to protein ratio of diets on deposition of fat and protein in the carcass of fattened lambs. 2. Experiments with diets equal in energy with different amounts of protein (in Bulgarian). Zhivot. Nauki 24 (11), 39-44

Sinclair L.A., Galbraith H., Scaife J.R., 1991. Effect of dietary protein concentration and cimaterol on growth and body composition of entire male lambs. Anim. Feed Sci. Tech. 34, 181-192

Statgraphics ${ }^{\circledR}$ Plus ver. 7., 1993. Statistical Graphics System by Graphics Corporation

Urbaniak M., 1986. Protein requirement of Merino lambs fattened from 20 to $40 \mathrm{~kg}$ live weight (in Polish). Rocz. AR Poznań, Rozpr. Nauk. No. 161

Żebrowska T., Żebrowska H., Ziołecka A., Pajak J., Dakowski P., 1987. The use of rye grain in fattening lambs (in Polish). Rocz, Nauk. Zoot., Monogr. Rozpr. 25, 61-73

\section{STRESZCZENIE}

\section{Skład tusz jagniąt polskiej owcy nizinnej i merynosa polskiego żywionych dawkami o różnej zawartości bialka}

Badano wpływ zawartości białka w dawkach na skład tkankowy tusz 90 jagniąt tryczków polskiej owcy nizinnej, żywionych w okresie tuczu dawkami zawierającymi od 13 do $18 \%$ białka ogólnego w s.m. oraz 44 tusz jagniąt tryczków merynosa polskiego, otrzymujących od 11 do $19 \%$ bialka w s.m. Tucz prowadzono od odsadzenia w wieku 70-90 dni do uzyskania masy ubojowej $35-40 \mathrm{~kg}$ (merynos polski) lub $35-45 \mathrm{~kg}$ (polska owca nizinna).

Jagnięta nizinne otrzymujące $w$ dawce mniej białka miały tusze nieco gorzej umięśnione $i$ bardziej otłuszczone niż jagnięta żywione dawkami o większej zawartości białka. U merynosów nie stwierdzono istotnych różnic w składzie tkankowym tuszy w zależności od poziomu białka w dawce. Skład tkankowy tusz zależał w większym stopniu od masy ubojowej i związanej z tym masy tuszy jagniąt niż zawartości białka $w$ dawce. 